\title{
Agriculture Co-operative Associations, Livelihood Income and Rural Households Welfare in Osun State, Nigeria
}

\author{
Idowu James FASAKIN ${ }^{1}$; Oladeji Olayide POPOOLA ${ }^{2}$
}

\author{
Department of Agriculture Economics, University of Ibadan, Nigeria
}

Emails: Idowufasakin2010@ gmail.com and oladejipopoola1@ gmail.com

Tel: $+2348066513923^{1},+2348030425801^{2}$

Article No.: 030419043

Type: Research

DOI: 10.15580/GJAS.2019.2.030419043

Submitted: 04/03/2019

Accepted: 10/03/2019

Published: 16/05/2019

\section{${ }^{*}$ Corresponding Author}

Idowu Fasakin

E-mail: idowufasakin2010@

gmail.com

Phone: +2348066513923

Keywords: Co-operative

Association, Livelihood incomes,

Probit Regression, rural

Households.
The prevalence of poverty among rural households in Nigeria has prompted various efforts on poverty reduction, and one way out of poverty for rural farmers is participation in cooperative associations. Therefore, this paper examined the effect of participation in agriculture co-operative associations on livelihood income and welfare of rural farmers in Osun State, Nigeria. Data were collected through multi-stage random sampling; descriptive statistics and Probit Regression Model analysis were used. It was observed that there were more male farmers $(62.16 \%)$ than female $(37.84 \%)$, mean age of the farmers was 37 years and most $(67.57 \%)$ of the farmers were married. Households size was (54.59\%) for (1-5) family with $45.95 \%$ having farming experience of $11-15$ years. Majority of the farmers derived their income from agricultural activities $(39.46 \%)$, though the primary occupation was not farming $(57.84 \%)$. Income level was $(42.6 \%)$ between $60,000-80,000$ Naira monthly and a larger percentage $(76.33 \%)$ are active members of co-operative associations. Credit accessibility was poor with $35.14 \%$, a contributing factor to low welfare status and poverty. The result of the Probit regression model showed that the coefficients of age, sex, years of education, level of monthly income, access to credit and size of the farm significantly affect participation in cooperation association in the study area. The coefficients of age, sex, size of the farm and access to credit were positive and significant at $1 \%, 5 \%$ and $10 \%$ respectively, while the coefficients of income level and level of education was negatively significant at $10 \%$. Farmers in the study area also keep different types of livestock and domestic animals like Goat, Sheep, Fowls(poultry), Pig and Catfish as either major, alternative or additional sources of income. It is therefore recommended that cooperative societies should integrate adult education as part of their empowerment programmes so as to boost the literacy level of rural members. Also, short term loans, credit and inputs access inform of empowerment should be made available to agriculture co-operative members so as to strengthen the bond in the association and to help increase the income level of co-operative members. 


\section{INTRODUCTION}

\subsection{Background of the Study}

There is an urgent interest in producer organizations such as cooperatives as an institutional tool to improve market participation of smallholder farmers, which has the potential of increasing farm incomes and reduce rural poverty (Bernard and Spielman, 2009; Bernard and Taffesse, 2012). It has been ascertained that improving the productivity, profitability and sustainability of smallholder agriculture is the main pathway out of rural poverty in developing countries. Institutional innovations are believed to play a crucial role in this as they can help farmers to overcome market failures (Hazell et al., 2010; World Bank, 2008). To have an effect on income and households' welfare, these emerging institutions need to be both, inclusive - i.e. poorer farmers need to participate - and effective - i.e. creating an impact on farmers' income and wellbeing. Cooperatives are often associated with collective actions and social capital and are therefore often thought to be more inclusive than other types of institutional innovations such as contract-farming. The ability of households to exchange or move surplus from a region of comparative advantage to a region with less potential within a country or across national borders is an important ingredient towards the growth of agriculture and the improvement of rural livelihood (Muchopa, 2011). Promotion of livelihood should be concentrated on human resources and people of grass root levels and they should be mobilized to work together voluntarily to make use of scarce resources at their disposal. Agricultural cooperatives play a vital role in enhancing rural dwellers income which will eventually promote their livelihood. People participate directly in agriculture and they create and increase productivity which are the major indicators for poverty reduction and promotion of livelihood in general (Chikaire, 2011). Enhancing the income of the rural poor becomes more urgent and this calls for organizations such as cooperative societies to use their potentials and resources optimally towards the satisfaction of their members' wellbeing.

The primary motive of promoting livelihoods is the belief in the essential right of all human beings to equal opportunities and ensuring that poor households have a stable livelihood which will substantially increase their income over a period of time. Cooperative Societies all over the world have been seen as one of the ways of reaching out to the households where banking activities are evidently absent, and not a few have come to see it as an alternative to the regular banking, since it, in most cases provides members of the group with financial incentives without the rigours usually experienced in banking halls (Adewakun, 2012).

Traditional cooperatives are common throughout Nigeria, but these groups tend to be small, with a common bond based on membership of a similarity, societal and low professional group (Adewakun, 2012). In some cases, savings and credit co-operative societies are known to provide funding to their members at reasonable interest rates and without the requirement of collateral. They are therefore vital organs for improving the welfare and livelihoods of the rural households (Mavimbela et al., 2010). Both government and non-governmental with international agencies at various levels have tried their best to improve livelihood of the people, but despite their concerted efforts, participation in co-operative associations among rural households is still very much in the doldrums (World Bank, 2005). Similarly, many studies and researches have been conducted in a bid to fill the lacuna in income disparity and inequalities of rural households Muchopa, (2011) and Chikaire, (2011). However, little research has been done on the extent to which participation in co-operative activities have been helpful towards combating poverty and improving the rural households' income in the study area, this study would attempt to fill this gap in research.

\subsection{Problem Statement}

Over the years, the concern and the threat posed by increasing poverty among rural households has led the Nigerian government and international agencies to devote considerable attention to alleviating its menace through various aid programmes, sometimes in collaboration with the civil society and donor agencies (Girei et al., 2013). Some of these programmes include: Agricultural Development Programme (1975), Operation Feed the Nation (1986), National Directorate for Employment (1987), National Fadama Development Programme I (1992), Family Support Programme (1996), National Poverty Eradication Programme (2001), Special Programme on Food Security (2001), National Fadama II Programme (2004), National Special Food Security Programme (2005), National Fadama III Programme (2009) and Subsidy Reinvestment and Empowerment Program (2013) SURE-P (NBS, 2015). Despite all these programmes and other policy measures, rural poverty is on the increase and the percentage of the population living below the poverty line in Nigeria is still a subject of concern to government and donor agencies (NBS, 2017). The willingness of the lowincome group to borrow and repay at seemingly high interest ascertain their inability to access the loans thus confirming problems attached with accessing funds the view that their financial problems has more to do with access to funds (Anyanwu, 2004). The poor lacked good credit history because they never gained access to credit in the first place, thus the poverty level continues to aggravate Akanji (2006) and Ojo (2009).

In recent times, cooperative associations have been trying to address members' demands by mobilizing funds and granting credit to members at no or low interest rates (Adeyemo and Bamire, 2005). However, they have not been able to grow their wealth sufficiently due to non-accumulation of enough capital to finance non-withdrawable capital funded assets, provide cushion to absorb losses and impairment of members' savings (Agrawal et al., 2002). Also, the 
federal government of Nigeria in conjunction with the World Bank, initiated the National Fadama Development Program, aiming at increasing the incomes of farmers, the program uses the community driven development approach which is being supported by an international development association credit facility (NFDP, 2009). The government also penetrated the local association and groups through the Growth Enhancement Support Schemes (GESS), to distribute farm inputs especially fertilizers to rural farmers through voucher system (FMARD, 2015). Despite all these programmes and various continuous empowerment schemes across the country, there has not been an adequate success for poverty reduction among the rural households in the country. In view of this and other aforementioned points, this paper will proffer answers to two research questions; what effects does participation in agriculture co-operative associations have on the livelihood income of the rural households, what are the factors affecting/challenges faced by rural farmers in participation in cooperative associations? These objectives will be examined in this research paper; examining the factors affecting participation in cooperative associations; identifying the challenges faced/factors affecting rural farmers in participating in agriculture co-operative associations in the study area.

\subsection{Literature Review}

The term "Cooperative" is as old as human creation. From the beginning, humans want to collaborate, work together or work as a team to achieve many of the tasks. The story of ancient Babylon is a good example, where people engaged in a form of cooperative activity in order to build the tallest building that would touch the sky. Many cultures live communal lives whereby individuals or groups help others to accomplish a goal with the belief that they would reciprocate whenever their help is required or needed. Thus, the term "cooperative entrepreneurship" dates back to ancient times. However, in recent times, the term "cooperative" is resurfacing under the current global economic challenges. Recently, authors in the area of cooperatives are gradually linking cooperatives with entrepreneurship, thus the term "cooperative entrepreneurship". According to Skurnik (2002), cooperative entrepreneurship is described as businesses owned by members, or group of customers, called customer-owners. They do not just own the business but are also in full control in the management of the business. It is a business organization which is open to all and members voluntarily joined with the aim of producing services in the interests of its members. The definition by Van der Walt (2008) described cooperative entrepreneurship as business organizations, voluntary and willingly established by group of people called members with common needs in order to apply this business into the community and also ensure that the actors called entrepreneurs are fully involved in all the activities. Collective entrepreneurship, which refers to producerowned firms, is often located at the level of the multiple producer-owners and at the level of the jointly-owned firm. Also, in looking into the new phenomenon of agricultural cooperatives, Van der Walt (2008) defined a cooperative as "a form of rent-seeking behaviour exhibited by formal groups of individual agricultural producers that combine the institutional frameworks of investor-driven shareholder firms and patron-driven forms of collective action', he argued that cooperative entrepreneurship which is a new form of business can be used to offer rural communities some techniques on how to deal with or cope in any economic situation which had failed to respond to the community's priorities in their quest to survive.

Nkechi et al., (2015) conducted a study on the effects of membership of cooperative organisations and determinants on farmer-members' income in rural Anambra state, Nigeria. Multiple regression technique i.e. the ordinary least squares (OLS) was employed to test the impact of socio-economic characteristics of members and some cooperative organisations related variables on income. The study found out that members' incomes are dependent upon their socioeconomic profile such as age, marital status, and membership or otherwise of cooperative societies, education, cooperative marketing, credit, gender and business expertise. Also, respondents depend largely on farming related activities for generation of income in the study area.

Taiwo et al., (2015) conducted a study on the effect of cooperative membership on the economic empowerment of women in Osun State of Nigeria. Data were obtained from 375 women co-operators across two senatorial zones of Osun State. Data obtained were analyzed with both descriptive statistics and inferential model of regression, T-test, ANOVA non-parametric correlation test as well post -hoc test. Evidence from the study revealed that socioeconomic variables of the respondents are determinant factors for their membership in cooperative societies. It was also revealed that women cooperative societies in Osun State are involved in different economic empowerment activities that are accessible and capable of empowering women in Osun State.

Gomina, (2013) conducted a study on the impact analysis of savings and credit cooperative societies in combating poverty among crop farmers in three Local Government Areas of Niger State, Nigeria. Foster-Greer-Thorbecke indices, double difference estimators, paired t-test and multiple regressions were used. Results of data analysis reveal that the mean ages of the farmer beneficiaries and non-beneficiaries were 41 and 38 years respectively. The results of poverty severity index revealed that about $2 \%$ of the beneficiaries constitute the poorest among the respondents, while about $4 \%$ of the non-beneficiaries constitute the poorest among the respondents after obtaining credit. The results from double difference estimator revealed that SACCOS Credit impacted positively on the beneficiaries" crop output and per capita annual farm income with a positive mean value of $290.03 \mathrm{~kg}$ and $2,054.77$, respectively. The results from multiple regression analysis revealed that household size, farm income, non-farm income, educational level and interest rate charged on credit were the significant factors that influence the level of 
participation in SACCOS at $1 \%$ and $10 \%$ levels of significance respectively.

Kareem et al., 2012 conducted a study on the impact of cooperative societies on capital formation using a case study of Temidere-cooperative and Thriftsocieties, ljebu-ode, Ogun state. They found out that the total amount deposited enhances the capital available to co-operators, majority of the loan collected by the co-operators ranges from $\$ 20,000-\$ 100,000$.

\subsection{METHODOLOGY}

\subsection{Study area}

The study was carried out in Osun state, Nigeria. Osun State has 3 Agricultural Development Project (ADP) zones, Osogbo, Iwo and Ife/ljesha. The ADP headquarters is at Iwo. The state is located in south-western Nigeria, and lies within latitude $7.0^{\circ}$ and $9.0^{\circ} \mathrm{N}$, and longitude $2.8^{\circ}$ and $6.8^{\circ} \mathrm{E}$. The state covers a total land area of approximately $8,602 \mathrm{~km} 2$ and lies between 300 and $600 \mathrm{~m}$ above the sea level with a largely gentle and undulating landscape. The average rainfall ranges from $1,125 \mathrm{~mm}$ in derived savannah to $1,475 \mathrm{~mm}$ in the rain forest belt. The mean annual temperature ranges from $27.2^{\circ} \mathrm{C}$ in the month of June to $39.0^{\circ} \mathrm{C}$ in December. The soil types are varied but most contain a high proportion of clay and are mainly dominated by laterite. The area is an agrarian community that engaged in crop, fishery and poultry productions. (Olasunkanmi and Yusuf, 2014)

\subsection{Type and sources of Data}

Primary data was used for this study. A structure questionnaire was used to elicit required information from the respondents. Information sought include respondents' characteristics such as age (year), sex, education level (years of formal education), household size (number of persons), marital status etc., information on livelihood activities of respondents and their various income sources were also collected; on-farm and off farm activities. Others are information on membership of cooperative societies, benefits derived from membership of cooperative society, reasons for not participating in agriculture cooperative associations.

\subsection{Sampling Technique and Sample size}

A multi-stage random sampling technique was used in this survey. First, was the purposive selection of Osun State, the second stage was the selection of four local governments based on the previous information gathered about agriculture co-operative association and agriculture production in the state. The third stage was the selection of rural communities and towns/villages, thereafter, the questionnaires were administered. In all, a total of 185 questionnaires were administered. Selection was randomly done based on probability proportionate to sizes. (PPs)

\subsection{Method of Analytical Data}

The analytical method that was used in this study includes descriptive analysis and Probit Regression Model. The socio-economic profile of the respondents was done with the use of descriptive statistics which involves the use of frequency, percentage and cumulative Percentage. This analysis captures the socio-economic roles of cooperative societies and the challenges to participation in cooperative societies.

\subsection{Probit Model}

The Probit model was used to determine the factors affecting participation of the farmers in cooperative associations. In statistics, probit model is a type of regression where the dependent variable can only take two values. It can also be said to be a unit of measurement of statistical probability based on deviations from the mean of a normal distribution. The standard normal distribution is commonly denoted as $N(0,1)$ and its cumulative distribution function as $\phi(Z)$. It is used in a number of different ways. The explanatory variables used in this model include socioeconomic characteristics; age, sex, marital status, household size, education status, level of income, size of farm land and primary occupation. The dependent variable is participation in cooperative society. It has two possible options; participate (member) or notparticipate (non-member) in cooperative. According Greene (1993),

$$
\begin{gathered}
y_{i}^{*}=X_{i} \beta+\varepsilon \\
y_{i}= \begin{cases}1 & \text { if } X_{j}>0 \\
0 & \text { if } X_{j} \leq 0\end{cases}
\end{gathered}
$$

This process gives the probit model;

$$
Y=\beta_{0}+\beta_{0} X_{1}+\beta_{0} X_{2}+\beta_{0} X_{3}+\beta_{0} X_{4}+\beta_{0} X_{5}+\beta_{0} X_{6}+\beta_{0} X_{7}+\beta_{0} X_{8}+\beta_{0} X_{9}+\beta_{0} X_{10}+\varepsilon_{0}
$$

Where

$\mathrm{Y}=$ Membership of the Association (yes $=1, \mathrm{no}=0$ )

$X_{1}=$ Age (years)

$X_{2}=$ Marital Status

$X_{3}=$ Years of formal education (years)

$X_{4}=$ Household size (number)

$X_{5}=$ Monthly income (naira)

$X_{6}=$ Access credit (yes $=1$, no $=0$ )

$X_{7}=$ Size of the farm land (hectares)

$X_{8}=$ Years of being a cooperative member (number)
$X_{9}=\operatorname{Sex}(1=$ male. $0=$ female $)$

$X_{10}=$ Education level (year)

$\varepsilon_{0}=$ Error term

\subsection{RESULTS AND DISCUSSIONS}

\subsection{Descriptive Statistics}


The result of the descriptive Statistics was shown in table 1.

From the table (i), the percentage of male respondents was $62.16 \%$ while the female respondents were $37.84 \%$, this showed that male farmers respondents were more than the female respondents. The age respondent showed that $31.35 \%$ of the respondents were between the ranges of 2140years, $37.84 \%$ were between the ages of 41 60years, $23.24 \%$ were between the ages of 61 80 years and $7.57 \%$ were in the range of $81-100 y e a r s$. This implies that productive ages of 41-60years are very active in cooperative societies and they are within the economic active age. Also, $14.05 \%$ of the respondents were single, majority of the respondents with $67.57 \%$ were married and $18.38 \%$ were divorced. It can be inferred that the highest percentage of people engaging in cooperatives are married and in economic productive age. Household size respondents were fairly large with $54.59 \%$ having household size of 1-6 and $45.41 \%$ with $6-10$ household size. Farmers in the study area are experienced in their farming activities, with $45.95 \%$ having $11-15 y e a r s$ of farming experience, $29.19 \%$ having 6-10years experience and 24.86 having 1-5years experience. The respondents are highly educated with $91.89 \%$ of the respondents having primary, secondary or tertiary education, with only $8.11 \%$ of the respondents having no education at all. Participation in farming as a primary occupation in the study area has declined, with $57.84 \%$ of the respondents claiming that non-farming activities is their primary occupation while $42.16 \%$ of the respondents see farming as their primary occupation. Despite the decline in participation in farming activities, about $39.46 \%$ of the respondents generated their income directly from agricultural activities, $29.73 \%$ derived from non-agriculture activities while $30.81 \%$ opined that they generate their income from both sources. Credit access is very poor among the farmers, as $64.86 \%$ of the respondents have no access to credit, while $35.14 \%$ have access to credit. Extension access is fairly good with $51.35 \%$ having access to extension services while $48.65 \%$ have no access. Participation in cooperative associations is high among the respondents with $76.33 \%$ of the respondents as active members of co-operative associations while $23.67 \%$ are non-members of any co-operative association. Sample farmers in the study area has vast experiences in co-operative association, as $36.76 \%$ of the respondents having 6-10 years of experience, $25.41 \%$ having $11-15$ years of experience, $23.78 \%$ having $1-5$ years of experiences and $14.05 \%$ having more than 16 years of experience. The level of income of the respondents varies across the study area, where $42.16 \%$ of the farmers earned between $60,000-80,000$ naira monthly income, $23.24 \%$ earned between 40,000-60,000 naira, $16.22 \%$ earned between 20,000 40,000 naira monthly while the least income earners are people with less than 20,000 naira monthly income being $4.32 \%$. The level of income of the farmers in the study was fairly large with $42.16 \%$ being the highest earners.

\subsection{Effects of Co-operative Associations' Membership on Farmers' Livelihood Incomes}

The Probit regression model was used to determine the effects of co-operative associations on farmers' livelihood incomes. The results show that age, gender, educational status, level of income, access to credit and size of the farm were the explanatory variables that significantly affect participation in cooperation associations either positively or negatively. While household size, contact with extension agents, marital status, and primary occupation on the other hand did not affect cooperation significantly.

The coefficient of age had a positive relationship with participation in cooperative and significant at $1 \%$. This implies that as the farmers get older, the probability of participating in cooperative associations increases, because old age is a synonymous or proxy with farmers' experience and farmers are getting exposed to different types of opportunities as they are ageing on the job. Also, sex had a positive relationship with participation in cooperative associations at $1 \%$ level of significance. The coefficient of sex increases probability of participation by $26 \%$. This means that, male farmers were active in cooperative societies than females farmers and this justifies the dominance of male farmers in the study area. The coefficient of years of education had a positive relationship with farmers' membership of association and was significant at $5 \%$, this showed the positive contribution of education attainment to co-operative association membership. Number of years spent in school increase the probability of participating in cooperative activities by $11 \%$. This means that, enlightened and educated farmers see more benefits in joining cooperative association than people that are not educated. The coefficient of income level has a negative relationship with participation in cooperative associations and was significant at $10 \%$. This is in conformity with general beliefs that low capital farmers or individuals cherish becoming co-operative association members, hoping that huge financial benefits will come from their participation. Farmers with large financial base can stand on his/her own without any alignment with any social organizations. Size of the farm had a positive relationship with participation in cooperative at $5 \%$ level of significant, which implies that a unit increase in the probability of farm size by one acre will increase the probability of the land. Size of the farm increases the probability of being in farming at $66 \%$ because almost half of the members of the cooperative societies were involved in farming activities, but majority of the members are benefitting from agricultural activities like crop and livestock rearing, fish culturing etc.

\subsection{Challenges Facing Agriculture Co-operative Association in the Osun State, Nigeria}

Table 3 showed the problems and challenges faced by agriculture co-operative association members in the study area. The challenges are ranked in order of the frequency. Nearly all the sample farmers (96\%) agreed 
that the purpose of joining co-operative associations is to gain access to government credit or finances but were unable to benefit from it despite the years they have been there. This is closely followed by lack of government assistance (87\%), where they said besides credit, other government assistance didn't reach their groups or localities. Diversion of incentives/aids (83\%) either from government or nongovernmental organization is another challenge identified by the farmers. Uncommitted membership $(65 \%)$ and poor leadership nearly have the same percentage as indicated by the farmers. (55\%) of the sampled farmers opined that members and executives hoarded some relevant information from each other, as they complain about preferential treatment and favouritisms among themselves. This boils down to the lack of trust and sincerity (43\%) as indicated by their response.

\subsection{Conclusion and Policy Implications}

This study analyzed the generality and efficacy of participation in agricultural cooperative associations and its effects on livelihood income in Osun State, Nigeria. It was find out that cooperatives are to some extent limited but that they are effective in improving rural incomes and reducing rural poverty. Our findings indicate that there are some challenges facing members of agriculture co-operative associations in the study area. Some of the challenges include, leadership problem, reduction in the level of trust in association, poor or inaccessible government assistance, hoarding of relevant information among members, corrupt activities among others. For a region where more than half of the rural population is poor, these are important effects and challenges. This study is in support of the emphasis on agricultural cooperatives as an institutional vehicle to boost the smallholder farm sector in Nigeria. The formation and management processes encourage democratic decision-making, economic advancement, leadership development and education. The public-private partnership between farmers, NGO and government will enhance knowledge of the roles co-operatives play as a tool for improving the socioeconomic well-being of the rural community and helping to boost the rural quality of life. All agricultural co-operative associations have considerable potential to fill the social-economic vacuum through the provision of goods, services and employment, which are needed in rural communities to increase farmers' performance and income. This is similar to findings in Rwanda on literature where on contract-farming is a widely studied institutional innovation. While there is a growing amount of recent evidence that contract-farming has a positive effect on farm performance and farmers' welfare (Bellemare, 2012; Dedehouanou et al., 2013; Rao and Qaim, 2011).

\subsection{Recommendations}

Based on the findings of this study, the following recommendations are made:

There should be establishment and reinvigoration of existing traditional and rural financial institutions for rural farmers, so as to make the accessibility of credit for their respective venture easier and closer to their localities. Agriculture co-operative associations should integrate adult education as part of their empowerment programmes, so as to boost the literacy level of the rural farmers and increase their chances of getting social and economic inclusion. Existing agricultural co-operative associations that are not registered should be registered with the new ones. The registration will bring them recognition in the state and disciplined executive members should be appointed in coordinating their affairs. Agriculture cooperative associations should also seek for more innovative programmes that will boost economic status of rural members, programmes such as fish smoking, bee keeping, cattle ranching, and other modern postharvest technologies, this will enable rural people to attain self-reliance as well as boosting their income. The importance of extension services to effective economic empowerment cannot be over-emphasized, and as such, the moribund extension services in the state should be re-invigorated. This will help in disseminating relevant information to groups and associations and mobilization of the groups in their respective locations will be easier. 
Table 1: Socio-economic characteristics of the Respondents

\begin{tabular}{|c|c|c|c|c|}
\hline Variables & & & Frequency & Percentage \\
\hline & & Male & 115 & 62.16 \\
\hline SEX & & Female & 070 & 37.84 \\
\hline & & $21-40$ & 058 & 31.35 \\
\hline AGE & & $41-60$ & 070 & 37.84 \\
\hline & & $61-80$ & 043 & 23.24 \\
\hline & & $81-100$ & 014 & 07.57 \\
\hline & & Single & 026 & 14.05 \\
\hline MARITAL STATL & & Married & 125 & 67.57 \\
\hline & & Divorced & 034 & 18.38 \\
\hline & & $1-5$ & 101 & 54.59 \\
\hline HOUSEHOLD SI & & $6-10$ & 084 & 45.41 \\
\hline & & $1-5$ & 46 & 24.86 \\
\hline FARMING EXPE & RIENCE & $6-10$ & 54 & 29.19 \\
\hline & & $11-15$ & 85 & 45.95 \\
\hline & & No Education & 015 & 8.11 \\
\hline EDUCATION LE & /EL & Primary & 028 & 15.14 \\
\hline & & Secondary & 044 & 23.78 \\
\hline & & Tertiary & 098 & 52.97 \\
\hline PRIMARY OCCU & PATION & Farming & 078 & 42.16 \\
\hline & & Non-farming & 107 & 57.84 \\
\hline SOURCE OF INC & OME & Agricultural & 73 & 39.46 \\
\hline & & Non-Agricultural & 55 & 29.73 \\
\hline & & Both & 57 & 30.81 \\
\hline ACCESS TO CR & EDIT & Yes & 065 & 35.14 \\
\hline & & No & 120 & 64.86 \\
\hline ACCESS TO & & Yes & 095 & 51.35 \\
\hline EXTENSION & & No & 090 & 48.65 \\
\hline INCOME & $<\# 20,00$ & & 008 & 04.32 \\
\hline LEVEL & A20,001 & $\$ 40,000$ & 030 & 16.22 \\
\hline & A40,001 & $\approx 60,000$ & 043 & 23.24 \\
\hline & $\# 60,001$ & $\$ 80,000$ & 078 & 42.16 \\
\hline & $>\$ 80,00$ & & 026 & 14.05 \\
\hline MEMBERSHIP & Yes & & 164 & 76.33 \\
\hline $\begin{array}{l}\text { OF } \\
\text { COOPERATIVE }\end{array}$ & No & & 021 & 23.67 \\
\hline & $1-5$ & & 44 & 23.78 \\
\hline YEARS IN & $6-10$ & & 68 & 36.76 \\
\hline COOPERATIVE & $11-15$ & & 47 & 25.41 \\
\hline ASSOCIATION & 16 and $a$ & ove & 26 & 14.05 \\
\hline
\end{tabular}


Table 2: Factors affecting Farmers Participation in Cooperative Associations in Osun State

\begin{tabular}{|c|c|c|c|}
\hline Variables & Marginal Value & Std. Errors & $p>/ Z /$ \\
\hline Age & 0.2663 & .04771 & $0.000^{* * *}$ \\
\hline Sex & 0.2575 & .08184 & $0.002^{* *}$ \\
\hline Marital status & -0.0169 & .08922 & 0.850 \\
\hline Education (years) & 0.1089 & .05543 & $0.038^{*}$ \\
\hline Household size & -0.0113 & .03727 & 0.761 \\
\hline Primary occupation & 0.04761 & .08841 & 0.590 \\
\hline Level of income (monthly) & -0.0559 & .03264 & $0.087^{*}$ \\
\hline Size of the farm & 0.0662 & .03503 & $0.059^{*}$ \\
\hline Access to extension & 0.04231 & 0.7954 & 0.4381 \\
\hline Access to credit & 0.0614 & 0.3218 & $0.053^{*}$ \\
\hline Number of observation & & 185 & \\
\hline Pseudo R Square & & 0.7543 & \\
\hline Log likelihood & & -149.962486 & \\
\hline
\end{tabular}

Table 3: Ranking of the Challenges facing Participation in Co-operative Association in the Study
\begin{tabular}{clc} 
S/N & Challenges faced & Percentage \\
\hline 1. & Poor/inadequate credit access & $96 \%$ \\
2. & Lack of government assistance & $86 \%$ \\
3. & Diversion of incentives/aids & $83 \%$ \\
4. & Uncommitted membership & $65 \%$ \\
5. & Poor leadership & $63 \%$ \\
6. & Information Hoarding among members & $55 \%$ \\
7. & Lack of Trust and Sincerity & $43 \%$ \\
8. & Social status and discrimination & $24 \%$
\end{tabular}

Source: Field Survey, 2018

\section{REFERENCES}

Adewakun, A. (2012), Cooperative as tool for enhancing financial inclusion, African Newspaper of Nigeria, Oct.13, P1.

Adeyemo, R. and Bamire, A.S. (2005). Savings and Investment Patterns of Cooperative Farmers in South-Western Nigeria. Journal of Social Sciences, 11(3): 183-192.

Agrawal, R., Raju, K. V., Reddy, K.P., Srinivasan, R. and Sriram, M. S. (2002). Member Funds and Cooperative Performance. Research Paper, Indian Institute of Management, State of Andhra Pradesh, India.

Akanji ,O. O. (2006). Microfinance as strategy for poverty reduction. CBN Economic and Financial Review, 4(39).

Anyanwu, C. M. (2004): Microfinance Institutions in Nigeria: policy, practice and potentials. Paper presented at the G24 Workshop on Constraints it growth in Sub-Saharan Africa, Pretoria South Africa, $29^{\text {th }}-30^{\text {th }}$, November.

Bellemare, Marc F. (2012) "As You Sow, So Shall You Reap: The Welfare Impacts of Contract Farming," World Development 40(7): 1418-1434.

Bernard, T., and D.J. Spielman. 2009. Reaching the poor through rural producer organizations. A study of agricultural marketing cooperatives in Ethiopia. Food Policy 34(1): 60-69
Bernard, T., and A.S. Taffesse. 2012. Returns to scope? Smallholders' commercialization through multipurpose cooperatives in Ethiopia. Journal of African Economies 21(3): 440- 464

Bernard, T., A.S. Taffesse, and E. Gabre-Madhin. 2008. Impact of cooperatives on smallholders' commercialization behavior: evidence from Ethiopia. Agricultural Economics 39(2): 147-161

Chikaire et al (2010) Cooperatives A vehicle for rural development, Imo State Nigeria Retrieved from http://www.sciencepub.net/nature

Dedehouanou, S. F. A., Swinnen, J. and Maertens, M. (2013), "Does Contracting Make Farmers Happy? Evidence from Senegal". Review of Income and Wealth, Volume 59, Issue Supplement S1, pages S138- S160

European Commission (2010). Employment in rural areas: Closing the job gap. Commission staff working document. Brussels.

Fadama II Facility in Alleviating Poverty on Food Crop Farmers in Adamawa State, Nigeria. Global Journal of Agricultural Research, 1(3):8-15.

FAO (2014) Guide to extension training: The framework of development. http://www.fao.org/docrep/t0060e/t0060e02.htm

Federal Ministry of Agriculture and Water Resources (FMAWR). (2015). National Programme for Food Security, 
Federal Ministry of Agriculture and Water Resources, Abuja, Management Association of Nigeria Journal, 8 (2), p. 107.

Green, W. H. (1993) Econometric Analysis, 6th edition. Prentice-Hall, New Jersey.

Gomina A, (2013) Impact Analysis of Savings and Credit Cooperative Societies in combating Poverty among Crop Farmers in three Local Government Areas of Niger State, Nigeria. The School of Postgraduate Studies, Ahmadu Bello University, Zaria,

Hazell, P., C. Poulton, S. Wiggins, and A. Dorward (2010). The future of small farms: trajectories and policy priorities. World Development 38(10): 13491361

Mavimbela, P., Masuku, M.B. and Belete, A. (2010) Contribution of savings and credit cooperatives to food crop production in Swaziland: A case study of smallholder farmers. African Journal of Agricultural Research, 5 (21):28682874.

Muchopa et al (2011). Evaluating Performance by Cooperative Value and Efficiency. Nigerian Journal of Cooperative Studies. 2(1), $39-54$.

National Bureau of Statistics (NBS, 2011) Annual Socio-Economic Survey: Nigeria Poverty Profile Report. Document produced by National Bureau of Statistic. Abuja, Nigeria. Retrieved from www.nigerianstst.gov.ng

National Bureau of Statistics (NBS, 2013) Nigerians living below poverty line: Retrieved on August 18, 2013, from Nigeria Politics online.

National Fadama Development Project III (2009). National Cooperative Development Policy Document, Abuja.

Nkechi, C.O., Charles O. and Uchenna (2015): Effects of membership of cooperative organisations and determinants on farmer-members' income in rural
Anambra State, Nigeria. International Journal of Scientific and Technology Research, 4(8):28-35

Olasunkanmi and Yusuf, 2014). Resource use efficiency in small scale catfish farming in Osun State, Nigeria. Sky Journal of Agricultural Research 3(1) 037 - 045,

Ojo, O. (2009). Impact of microfinance on entrepreneurial development: the case of Nigeria: The International Conference on Administration and Business. ICEA - FAA, 14th $-15^{\text {th }}$ November.The Faculty of Business and Administration University of Bucharest

Rao, V., Ibanez, A. M., 2003. The social impact of social funds in Jamaica: A mixed-methods analysis of participation, targeting, and collective action in community-driven development. World Bank Policy Research Working Paper no. 2970.

Skurnik, S. (2002). The role of cooperative entrepreneurship and firms in organizing economic activities-Past, Present and Future. LTA, Issue1,103-124.

Taiwo Abdulahi Olabisi, Udunze Ugochukwu MacDonald, Agbasi Obianugu Emmanuela. Effect of Cooperative Membership on the Economic Empowerment of Women in Osun State of Nigeria. International Journal of Business and Economics Research.Vol. 4, No. 2, 2015, pp. 21-29. doi: 10.11648/j.ijber.20150402.11

Van de Walle, D., Cratty, D., 2002. Impact evaluation of rural road rehabilitation project, The World Bank, Washington, DC

World Bank (2005) Report on poverty and hunger across the world. A World Bank document available at www.worldbank.org

World Bank (2008) Report on Sustainability and poverty in Africa and the world. A World Bank document available at www.worldbank.org 